\title{
Central Banking and Inequalities: Old Tropes and New Practices
}

Clément Fontan, UCLouvain et USL-B

Peter Dietsch, University of Victoria

François Claveau, Université de Sherbrooke

Jérémie Dion, Université du Québec à Montréal

\begin{abstract}
This paper presents a critical analysis of the stance taken on inequality by two central banks since 2015: the Bank of Canada (BoC) and the Federal Reserve (Fed). The analysis is informed by a computer-assisted discourse analysis of how central bankers from the two institutions position themselves when it comes to issues of inequality. We observe that the position on inequality of the two central banks has changed in recent years and continues to do so. We argue that the stance on inequality taken by the $\mathrm{BoC}$ and the Fed suffers from a number of both inconsistencies and shortcomings. On the one hand, the $\mathrm{BoC}$ and the Fed claim that monetary policy instruments are too blunt to target specific sectors of the economy. On the other hand, with their response to COVID-19, they have demonstrated that such targeting is possible after all.
\end{abstract}

Keywords. Monetary policy, Central banking, Distributive consequences, Inequalities, Federal Reserve, Bank of Canada

JEL Codes. A13, D63, E58

Chapter forthcoming in Kappes, S., Rochon, L.P. \& Vallet; G. (eds). Central Banking, Monetary Policy and Social Responsibility, Cheltenham, UK: Edward Elgar.

Corresponding author: Clément Fontan $<$ clement.fontan@uclouvain.be $>$ 


\section{Introduction}

In the years following the financial crisis of 2007, central banks earned the reputation of being "the only game in town" in macroeconomic policy (El-Erian 2017). Faced with the risk of financial market collapse, they turned to unconventional monetary policies such as quantitative easing to weather the storm. They justified their actions by stating that extraordinary times required extraordinary measures.

When the COVID-19 crisis hit in March 2020, central banks quickly reverted to their 2007 playbook and even doubled down on it. They launched large stimulus programmes to keep the economy afloat during extended lockdowns and periods of both suppressed demand and breakdowns of international supply chains. Their balance sheets swelled once again, as shown in Figure 1 for the Bank of Canada and the US Federal Reserve. Looking back over the last 15 years, the extraordinary has become the norm (Best 2018).

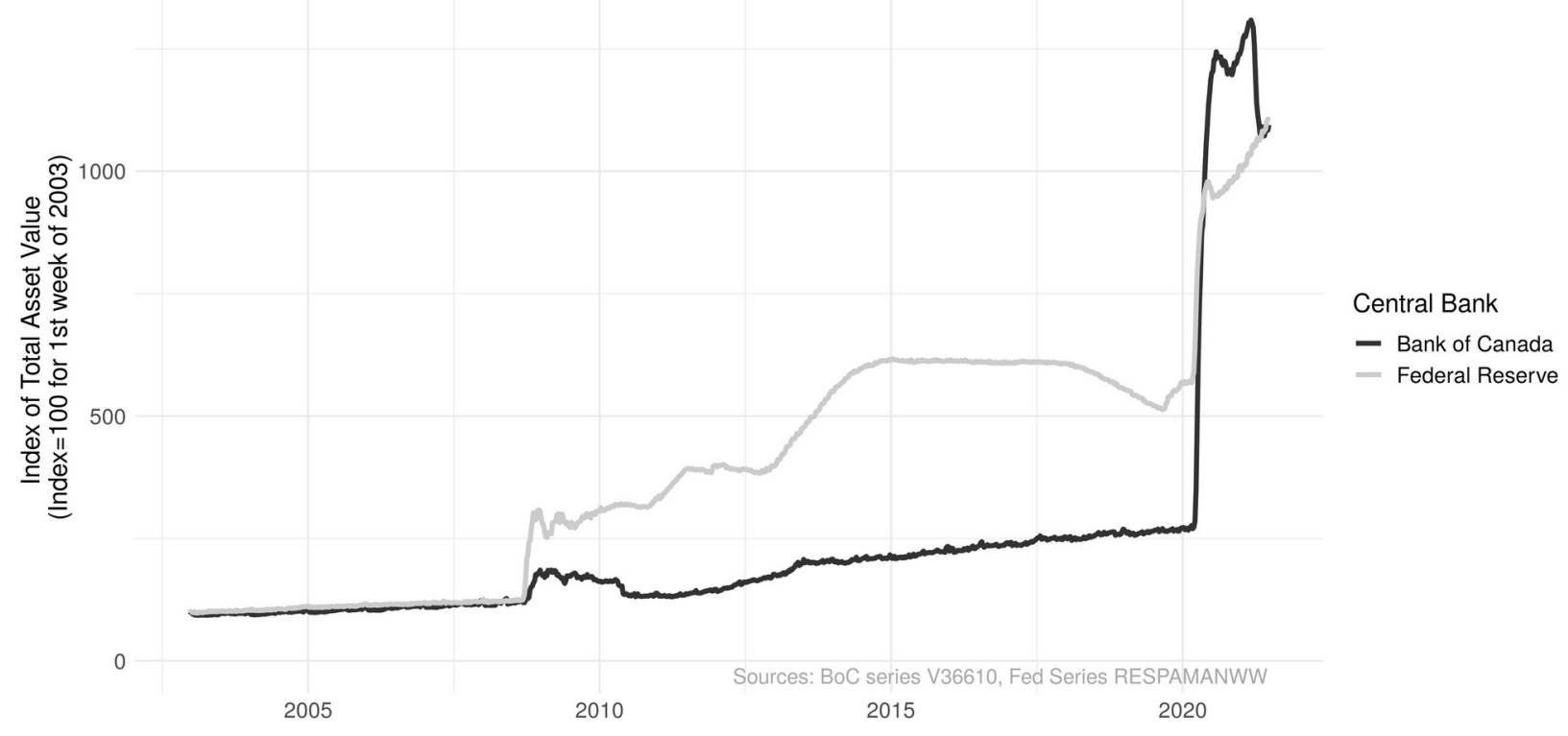

Figure 1: Total asset value of two central banks indexed at their early-2003 levels

The unconventional monetary policy instruments used over this period have unintended sideeffects. In particular, they affect the distribution of income and wealth in society through a variety of channels. Since unelected officials such as central bankers are not supposed to make deeply political decisions (Tucker 2018), they have come under increasing public pressure to justify their policies in light of these distributive consequences. 
This paper presents a critical analysis of the stance taken on inequality by two central banks since 2015: the Bank of Canada (BoC) and the Federal Reserve (Fed). ${ }^{i}$ The analysis is informed by a computer-assisted discourse analysis of how central bankers from the two institutions position themselves when it comes to issues of inequality. Can the stances taken by BoC and Fed officials be justified from a normative perspective? In other words, do they stand up to scrutiny when evaluated not just within the narrow confines of central bank mandates, but from a broader perspective that sees central banks as one cog in the institutional wheels of societies that pursue a number of sometimes conflicting objectives?

We use this analysis to make one observation and present one argument. We observe that the position on inequality of the two central banks has changed in recent years and continues to do so. We argue that the stance on inequality taken by the $\mathrm{BoC}$ and the Fed suffers from a number of both inconsistencies and shortcomings. Most importantly, their unprecedented actions during the COVID crisis belies the old trope that they cannot contribute to fight inequality because their tools are too blunt.

The methodological details of our computer-assisted discourse analysis are in a web appendix on Zenodo where we describe, justify and share our code and our corpus (1,494 documents from the Fed and 646 from the BoC). ${ }^{\text {ii }}$ The chapter thus focuses on the substance of our analysis. In the next section we provide a short primer on central banks and inequality to situate the argument of the paper in the conceptual landscape. The two main sections of the paper focus on the inter-crisis period (2015-2020) and the COVID-19-response respectively. The former is structured around three questions: Why care about inequality? Do central bank actions impact inequality? Should central banks fight inequality? In the section covering the COVID-19 crisis, we highlight a stark tension. On the one hand, the $\mathrm{BoC}$ and the Fed claim that monetary policy instruments are too blunt to target specific sectors of the economy. On the other hand, with their response to COVID19 , they have demonstrated that such targeting is possible after all.

\section{Central banks and inequalities - a conceptual primer}

Central bank actions and socio-economic inequalities connect in several different ways. To avoid confusion, it is key to distinguish some of these connections up front. The distinctions drawn here will underpin the structure of our analysis throughout the chapter.

First, it is surprisingly untrivial to point out that central bank actions and socio-economic inequalities $d o$ in fact connect. One of the most persistent myths in scholarship on money has been the idea that money constitutes a mere veil, and that it does not affect the real economy including inequality - in the long run (e.g. Ingham 2020). Among the more recent defenders of this position were the monetarists of the late $20^{\text {th }}$ century led by Milton Friedman. Let us call the 
debate about the neutrality of money the "old" debate concerning the link between central bank actions and inequality.

Even though the idea that money is neutral is intellectually dead and not borne out by the facts (Tobin 1972, Blanchard \& Summers 1992, Minsky 1993, Ingham 2004), it still has a surprising grip on some scholars and policy makers. ${ }^{\text {iii }}$ Incidentally, if money was in fact neutral, it would be hard to find proper justifications for the radical interventions of other central banks in the economy since the GFC over the last 15 years ago (Rochon et al., 2012). This acts as a distraction and obscures from view what one might call the "new" debate on the link between central bank actions and inequality. It is this new debate that lies at the heart of this paper.

We distinguish three facets of this debate that will structure our discussion below. ${ }^{\text {iv }}$

First, why do we or should we care about socio-economic inequality? Anyone, including central bankers, might care about inequality for two reasons. On the one hand, the reason can be instrumental. To the extent that inequality undermines the attainment of an objective one has, one should care about the reduction of inequality as a means to this end. For instance, central bankers should care about inequality to the extent it undermines their mandate (typically, price stability and financial stability). On the other hand, inequality matters not only for instrumental reasons, but in its own right. As we shall see, the position of central bankers on inequality as an intrinsic bad has evolved since the financial crisis and continues to do so.

The second facet of the debate is whether central bank actions themselves exacerbate inequality. As we shall see, the unconventional monetary policies employed by central banks since 2008 have been criticized for their unintended negative side-effects on inequality. Is this criticism justified?

Finally, independently of whether or not monetary policy has distributive effects, the third facet focuses on the question whether central banks should play a role in fighting inequality. Once we recognize the potential of money as a "social technology" (e.g. Ingham 2020, 7; Hockett and James 2020), then how can central banks justify not tapping into this potential more actively? The three facets just sketched overlap both in theory and in practice. However, they still prove useful in exploring different levels of engagement by central banks when it comes to the issue of inequality.

\section{The inter-crisis period (2015-2020)}

Between the two crises, the Fed and the BoC intensified their analysis of income and wealth distribution. On the one hand, the two central banks engaged with a wide range of economic actors to have a better understanding of the distributive dynamics during the economic recovery. 
On the other hand, they augmented their research activities on the distributive consequences of conventional and unconventional monetary policies. Some of their analysis was performed in the context of reviews of the banks' respective policy frameworks. Since 2001, the BoC has completed a review of its inflation-targeting framework every five years, culminating in a renewal of its mandate with the Government of Canada. Following the completion of one of its reviews in 2016, the BoC launched its "Toward 2021" initiative in 2017, laying the groundwork for the 2021 renewal of its mandate. ${ }^{\mathrm{v}}$ The BoC's latest review included research activities as well as numerous outreach activities in the form of workshops, surveys and focus groups. Similarly, the Fed engaged in 2019 in the first-ever public review of its monetary policy framework. Dubbed "Fed listens," it included 19 dedicated meetings with a wide range of stakeholders, a related research agenda and a discussion of the outcome of the review among policymakers. These activities were conducive to move the issue of inequality up the agenda at both central banks. In this section, we study whether and how the discourse on inequality from representatives of our two central banks changed prior to the onset of the COVID crisis. We show that, despite a richer engagement with distributive considerations than in the previous years, central bankers still used questionable tropes.

\section{Why care about inequality?}

As we have shown in previous work (Fontan et al 2016), central bankers have generally recognized the instrumental importance of taking inequality seriously and at least some of them signal that some forms of inequality - e.g., inequality of opportunity for the Fed - are intrinsically bad. Back in 2007, Ben Bernanke from the Fed summarized these two kinds of reasons: "Equality of economic opportunity appeals to our sense of fairness [intrinsic reason], certainly, but it also strengthens our economy [instrumental reason]."vi

At the Bank of Canada, Carolyn Wilkins elaborated in 2017 on the idea that inequality should be a concern of central bankers for instrumental reasons. According to her, more income inequality could lead to more "financial instability" and "alter the channels through which monetary policy actions affect the economy." their current mandates, central banks should instrumentally care about inequality. Indeed, if inequality threatens one of their mandated goals - e.g., financial stability - or if it weakens their capacity to accomplish their mandate by disrupting the channels through which they affect the economy, it will be relevant for monetary policy decisions. 


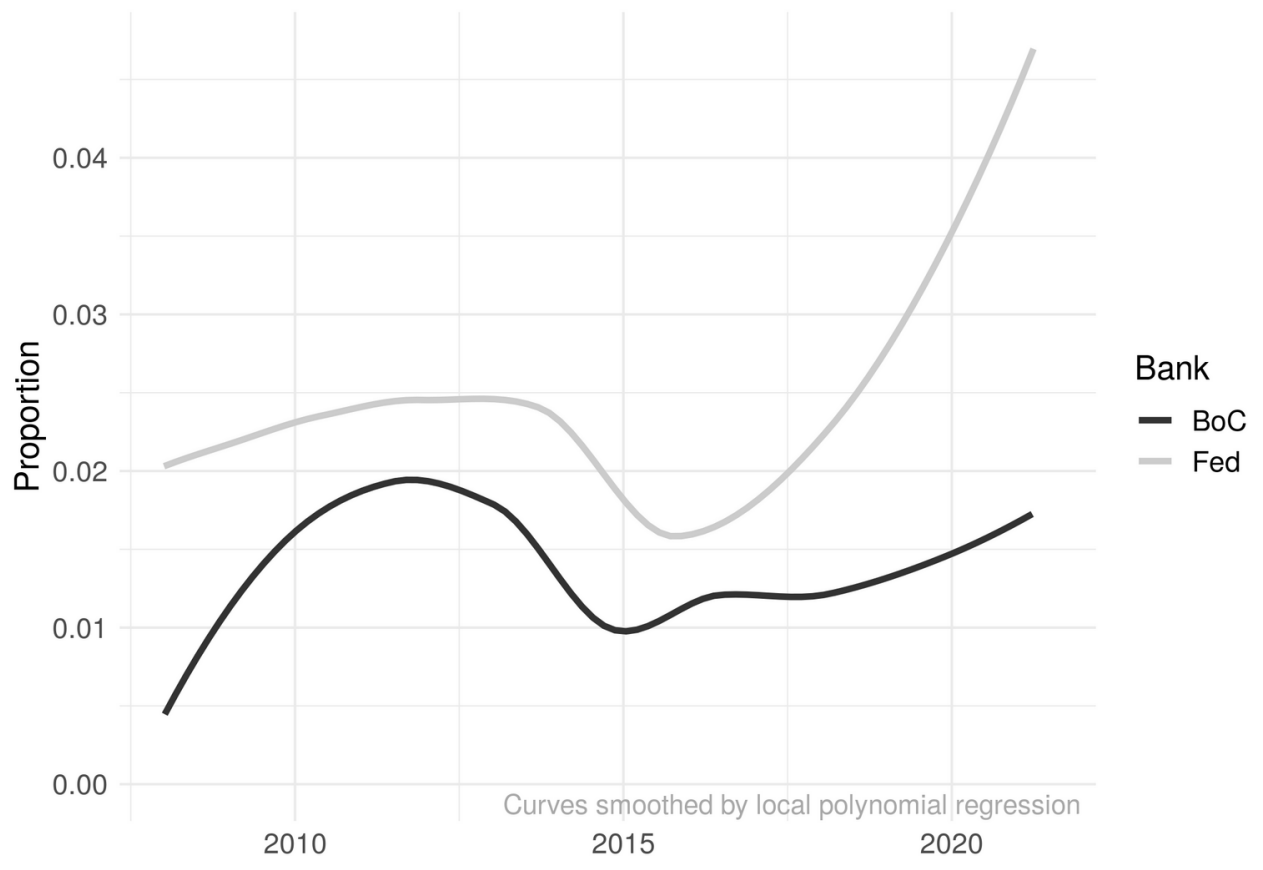

Figure 2: Proportion of paragraphs on inequality or poverty in speeches since 2008. Paragraphs are identified as discussing these themes based on the presence of one of our terms related to inequality and poverty (see the technical appendix for the list of terms)

Another indicator that central banks care about inequality is the extent to which they monitor and discuss distributive dynamics. From Figure 2 we can see that the Fed signals this kind of concern with inequality more frequently than the Bank of Canada. Indeed, since 2008, the proportion of paragraphs in speeches with at least one of our keywords is systematically higher for Fed than for BoC officials. Furthermore, we see that, after a trough in 2015-2016, Fed officials have spoken more frequently about the topic in the late inter-crisis period while Bank of Canada officials have been slightly more outspoken only since the onset of the Covid-crisis.

During this period, central bankers sometimes continue to frame inequality in terms typical of the $20^{\text {th }}$ century: "You know, the stagnation of middle-class incomes, the relatively low mobility that we have, the disappointing level of wages over a long period of time, it is all of a piece." viii The implicit representation of how society is structured here is between levels of income (middleclass and upper-class, with a limited mobility from one to the other) and sources of income (wage earners versus employers or investors). 


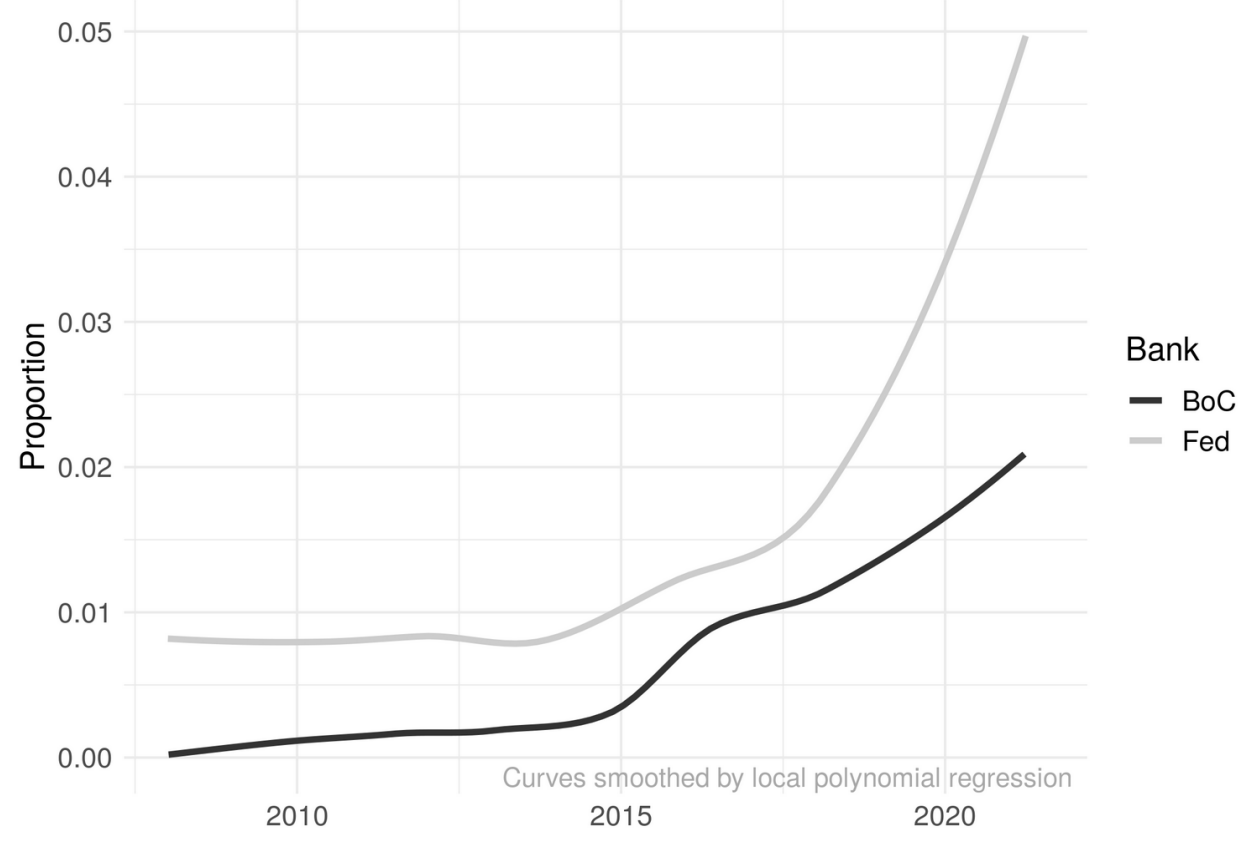

Figure 3: Proportion of paragraphs mentioning women, minorities or inclusion in speeches since 2008. Paragraphs are identified as discussing these themes based on the presence of at least one keyword (see the technical appendix for the regular expression used)

Yet, another frame has gained prominence in the period, foremost in the United States: inequality as concerning the relationship of some social or ethnic groups and communities with the rest of society. As Figure 3 shows, central bankers at the Fed and to a lesser extent at the Bank of Canada have been increasingly outspoken about concerns for women, for poor neighborhoods and especially for minority communities (African Americans, Native Americans, Hispanics). One way to characterize this shift is to say that the emphasis in concern with socio-economic inequalities has shifted from a primary concern with the economic dimension and the distribution of resources to various aspects of the social dimension that structure the economic dimension, such as race or gender. ${ }^{\text {ix }}$

This increasing importance of 'inclusive growth' in the discourse of central bankers is partly due to them being pressed by elected officials and activists on the issue. For instance, Yellen replies in 2016 to congressmen that "there are subgroups of the population who experience lower income and more distress in the labor market" and "there remains so much distress among African Americans". ${ }^{x}$ On the activist front, the "Fed Up" campaign, ${ }^{\text {xi }}$ started in 2014, questioned the Fed 
on issues of inequality, diversity and inclusion and led to a meeting at Jackson Hole on August $25^{\text {th }}, 2016$ between activists and Fed officials. ${ }^{\text {xii }}$ During the Jackson Hole meeting, Fed officials endorsed the campaigners' concerns in strong terms. Regarding the US economy, Neil Kashkari from the Minneapolis Fed maintained: "[W]e want this economy to work for every single American, every single one."xiii And Loretta Mester from the Cleveland Fed added: "[W]e're Federal Reserve people, but we're citizens of the United States, and we want the United States to be - right? - the best it can be for all its people."xiv

During the same Jackson Hole meeting in 2016, Fed officials promised to ramp up research on economically marginalized communities and to have more regular meetings with organizations serving these communities. They have followed up on these promises. In March 2017, at the National Community Reinvestment Coalition which aims at directed credit towards "low- and moderate-income neighborhoods", Janet Yellen recognized that "while the job market for the United States as a whole has improved markedly since the depths of the financial crisis, (there is a) persistently higher unemployment rate in lower-income and minority communities." ${ }^{\mathrm{xv}}$ Most significantly, the Fed Listens initiative in 2019 involved many meetings discussing concerns relating to inequality, diversity and inclusion. Clarida recounts some of the encounters: "In Dallas, we heard from local leaders about the challenges facing lower-income communities. In Minneapolis, we listened to researchers discuss the distributional consequences of the economic cycle and of monetary policy."xvi

In sum, from 2015 to 2020, central bankers have recycled some usual tropes about why inequality should be a concern, but their discourse has also shifted on this issue, especially so at the Fed. First, Fed officials have discussed the topic more frequently since 2016. Second, the Fed has significantly ramped up research on how marginalized groups and communities are affected by inequality. One potential explanation of the difference in discourse and research emphasis on this issue compared to the BoC lies in the dual-mandate of the Fed. As Wilkins of the BoC puts it, "Canada's framework is less definitive about the importance of employment and labour-market conditions in determining the appropriate path for interest rates." ${ }^{\prime x v i i}$ Another potential explanation is the centrality of race to US politics. Yet, we will see that the $\mathrm{BoC}$ has been in catch up mode on this issue during the COVID crisis.

\section{Do central bank actions impact inequality?}

For central bankers, it is one thing to say that they care about inequality, but quite another to say that their actions have impacted inequality in the past or could deliberately impact it in the future. We will see in this section and the next how their discourse on these two dimensions has evolved in conflicting directions during the inter-crisis period. 
Although QE and other tools have been in the central bank toolbox for more than a decade now, the distinction between conventional and 'extraordinary' measures is still used in the context of discussing the distributive impact of monetary policy. We will thus use it to structure this section.

The 'conventional' tool of central banks is short-term interest rate setting through open-market operations on a limited class of assets (typically, sovereign bonds). Unconventional monetary policy mostly refers to QE, i.e. the purchase of assets on financial markets with newly created central bank reserves. When asked about the distributive impact of conventional monetary policy, central bankers have various answers that do not sit well together.

First, Wilkins from the Bank of Canada resurrects the idea that an alleged neutrality of money implies that monetary policy cannot affect a structural property such as inequality: "monetary policy — which is neutral in the long run — cannot fix structural problems." ${ }^{\text {xviii }}$ Second, and in a move difficult to square with Wilkins' claim about money neutrality, in its 2016 policy review the Bank of Canada provided an estimate of the redistributive impact of increasing its inflation target from 2\% to 3\% (Bank of Canada 2016, box 4; see also Amano et al 2017). The estimated effects vary between $-2.69 \%$ and $+1.14 \%$ of net wealth across wealth and age groups and thus clearly show that, according to the BoC's own models, the choice of monetary policy does have distributional consequences. ${ }^{\text {xix }}$ Furthermore, it indicates that the overall distributional impact of a monetary policy is a composite effect of changes affecting different groups in opposite directions. It is thus not a question that can be answered easily by pointing to one factor.

Yet, and this is their third typical reply, central bankers tend to quickly brush aside the question by pointing to a factor that puts them in a good light. For instance, Fed officials like to point to their goal of maximum employment as being good for the poor, and they draw invalid conclusions on that basis: "No, we don't think monetary policy is exacerbating inequality. We think, in fact, it is helping those who didn't have jobs get jobs." ${ }^{\mathrm{xx}}$ The dynamics is not necessarily that simple: even if some jobs are created, inequality can still go up if the well-off get a disproportionate part of the newly baked pie.

In sum, central bankers seem to think that the distributional effects of conventional monetary policy are barely worth discussing. By contrast, in our previous analysis for the period between 2007 and 2015 (Fontan et al 2016, pp. 333-335), we found that many central bankers were more concerned about the unequal impacts of their actions when it came to unconventional monetary policy. Based on early research (e.g., Bank of England 2012; Coibion et al. 2012), central bankers maintained that, although QE had adverse distributive effects, the extraordinary situation of the Great Financial Crisis implied that these unintended side-effects had to be tolerated. 
Since 2015, the position of central bankers on the distributive effects of quantitative easing has been informed by new research on the topic by central bank staff and academic economists. We expose several reasons to worry about some strands of this research and its uses by central bank officials. ${ }^{\mathrm{xxi}}$

According to a review of this literature, two main channels with opposite effects explain why some models conclude that quantitative easing increases economic inequality while other models conclude the opposite (Colciago, et al, 2019). In the case of income distribution, the main 'direct' effect of $\mathrm{QE}$ is to increase the value of financial assets, which exacerbates inequality as these assets are disproportionately owned by the wealthy. However, there is also a significant 'indirect' effect, reducing inequality by stimulating the economy: an expansionary monetary policy reduces unemployment and stimulates wages, which mainly benefits the less privileged. The relative impact of these two channels on wealth distribution depends on the distribution and composition of household assets and debts.

A recent article has found that central banks, in their own research, tend to measure stronger indirect effects of quantitative easing compared to studies conducted by independent academics, which implies that they tend to find that unconventional monetary policy helps to decrease inequality more than other researchers do (Fabo et al, 2021). What could explain this difference? The distinction between 'direct' and 'indirect' effect indicates that one is easier to measure than the other. Direct effects involve the increase in the value of financial assets, a phenomenon that nobody disputes, central bankers included. Indirect effects are about stimulating the economy. Here the attribution of responsibility to monetary policy is much more difficult.

Moreover, the measures of inequality used in the monetary economics literature probably do not correspond to what one would want to call more or less unequal distributions. Take the left-hand panel of Figure 4, which is a reproduction from an influential ECB study (Ampudia et al. 2018: Fig. 4). It reports the results of a simulation of the impact of ECB policies on the distribution of wealth (similar results for income can be found in Lenza and Slacalek, 2018: fig. 8). According to the authors, these results should lead us to conclude that the ECB's actions have reduced wealth inequality. The percentage representation hides a huge disparity in growth in monetary values as demonstrated by the right-hand panel in Figure 4, which represents the same data in a different way: $2.5 \%$ of $€ 1,100$ does not even correspond to an increase of $€ 30$ for the bottom quintile, while the median wealth of the top quintile increases by over $€ 5,000$ ! Although this simulated increase is associated with a slight decrease in the Gini index, it does not seem appropriate to celebrate it as a contribution to the decrease in income inequality. 

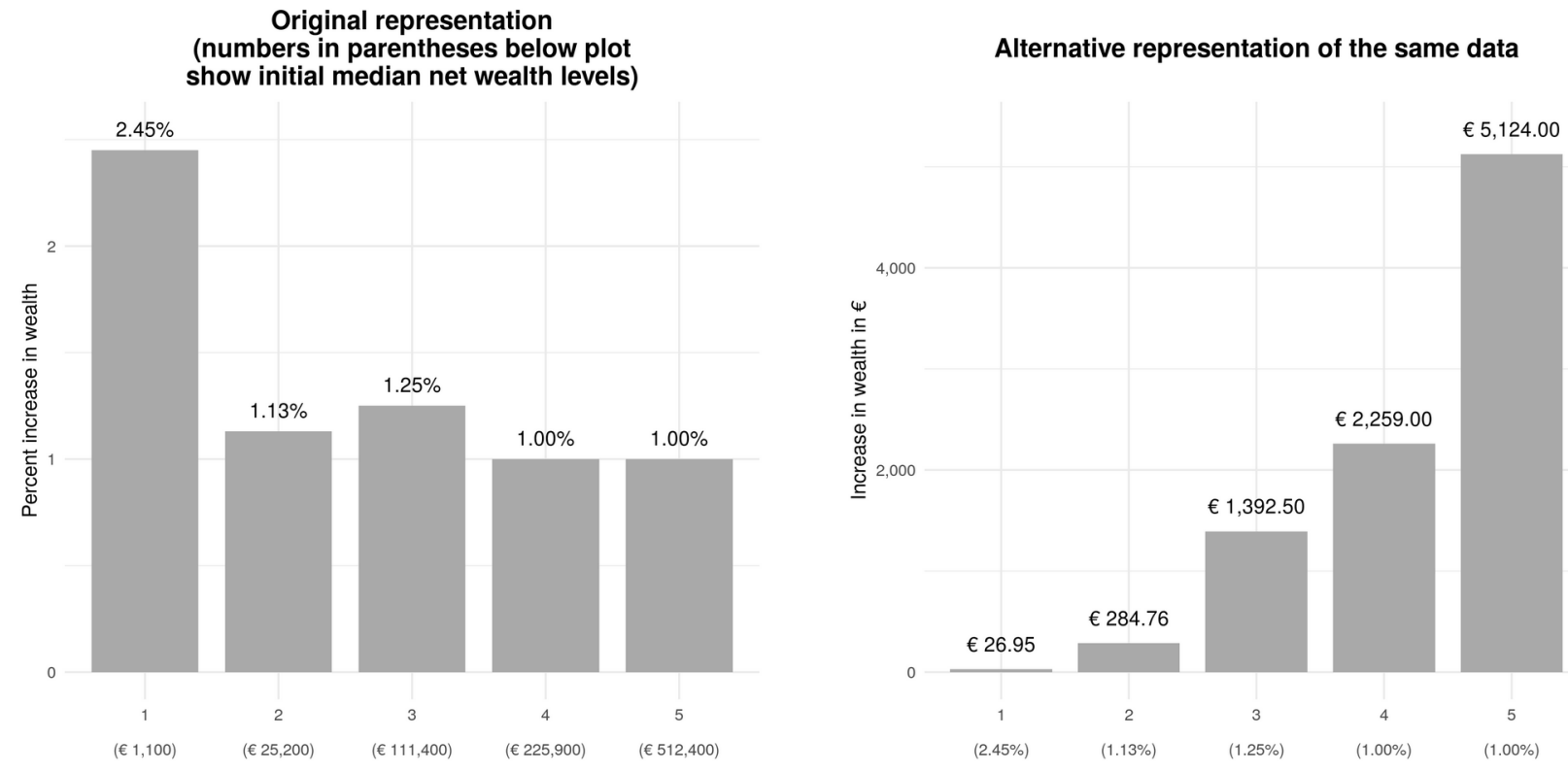

Figure 4: Two representations of the alleged effects of the ECB Asset Purchase Programme on the median net wealth by wealth quintile (data and original plot from Ampudia et al. 2018)

Another weakness of the literature on the distributive effects of monetary policy is the lack of precision as to which counterfactual scenario is considered (Bivens, 2015). Indeed, any causal claim implies a counterfactual scenario: a given monetary policy will have unequal effects compared to another policy. For example, one may ask what the effect of the Fed's QE on income distribution was compared to a policy limited to keeping the policy rate as close to zero as possible, that is, a policy that refrained from unconventional measures. The assessment of the distributive effect will not, however, be the same if the counterfactual scenario includes alternative policy measures, such as for instance the substitution of monetary action by a fiscal stimulus or the use of helicopter money instead of QE. In general, the literature assumes the first type of counterfactual scenario (i.e. a scenario of "no policy intervention" rather than "alternative policy intervention"). It thus misleads us to think that we cannot have the positive "indirect" effects without the negative "direct" effects.

All of these considerations imply the need for a nuanced interpretation of where the evidence stands on the issue of the distributive effects of QE. Yet, central bankers at the Fed and the BoC tend to deflect attention to other potential causes of inequalities when their policies extraordinary or not - are under scrutiny. Back in 2012, then Senior Deputy Governor Macklem from the Bank of Canada asserted that reducing inequality "is a complex subject involving a 
broad range of factors and the full array of policy frameworks, including education, health, openness to trade, foreign investment, financial development, and fiscal, labour market and environmental policies." $x x i i$ The discourse is similar at the Fed with Yellen maintaining that causes of rising inequality are shifts in demand for workers with "higher education and a more versatile skill-set, [...] changes in the minimum wage, declining unionization and executive compensation practices," "xxiii while Powell later added "low mobility," declining "labor force participation among prime-age males," and the "opioid crisis."xxiv While central bankers are certainly right in pointing out that there are multiple causes underpinning rising inequality, their position that monetary policy is not among them rests on shaky foundations.

\section{Should central banks fight inequality?}

This last line of reply to the question of whether monetary policy causes inequality is used by central bankers to deflect the next question, about who should address inequality:

[Rising inequality] unfortunately reflect[s] structural challenges that lie substantially beyond the reach of monetary policy. Monetary policy cannot, for instance, generate technological breakthroughs or affect demographic factors that would boost real GDP growth over the longer run or address the root causes of income inequality. And monetary policy cannot improve the productivity of American workers. Fiscal and regulatory policies--which are of course the responsibility of the Administration and the Congress--are best suited to address such adverse structural trends. ${ }^{\mathrm{xxv}}$

The most common position of Fed and BoC central bankers from 2015 to 2020 was thus that fighting inequality was best left to other institutions. The reasons that we highlighted in our analysis of the previous period (Fontan et al. 2016, pp. 340-345) are voiced again. Most importantly, central bankers claim that their tools are too blunt. They allegedly "don't have tools in monetary policy to target particular groups." $x x v i$ Although it might have been somewhat plausible in the early 2000 s, this claim seems quite a stretch now, especially since the creative response to the COVID pandemic (see the next section). But, even during the inter-crisis period, the claim that monetary policy is too blunt was in tension with other parts of the discourse of central bankers.

Recall that, in the context of reviewing its monetary framework for the 2016 mandate renewal, the Bank of Canada studied the "Redistributive Effects of the Transition to a Higher Inflation Target" (Bank of Canada 2016, box 4). Inflation targeting through 'conventional' monetary policy is the bluntest arrow in the central banker's quiver. Yet, if we are to believe this study, there are measurable distributive effects of a change of the inflation target. There is a potential to affect inequality, but the BoC's reasoning suggests that it is not seriously interested in exploring this potential. 
Instead of thoroughly analyzing the issue, the BoC's study takes a shortcut to conclude that the status quo, i.e. its two percent inflation target, is preferable. More precisely, the BoC claims raising the inflation target would be a bad idea because the number of households that would experience net losses in net worth as a result would be bigger than the number of households experiencing gains. ${ }^{\text {xxvii }}$ This conclusion relies on a highly controversial normative criterion. What normative theory on income and wealth inequality assesses policy proposals by appealing to the number of households positively or negatively affected? Standard approaches tend to appeal either to a utilitarian criterion - maximize the well-being of the greatest number - or to a maximin criterion - maximize the position of the least advantaged (Rawls 1999). Incidentally, note that on the maximin criterion, the BoC's data may well lead to the opposite conclusion from that presented by the $\mathrm{BoC}$, because the households that would benefit from a rise in the inflation target are poorer, younger households (see Bank of Canada 2016, Table 4-C). What can we learn from this BoC study? First, even conventional monetary policy is not necessarily too blunt to affect inequality. Second, the $\mathrm{BoC}$ needs to refine its position on what kind of inequality matters and why.

As to the Fed, the key question is to what extent its push for inclusive growth, visible in both its discourse and research during the inter-crisis period, translated into any willingness to do something about inequality. In other words, did "Fed listens" lead to "Fed acts" when it comes to inequality, and to a recognition that monetary policy tools may not be too blunt after all?

There are three elements to answering this question. First, Fed officials emphasized the synergies between expansionary monetary policy and promoting inclusive growth. For example, the outcome of the latest policy review by the Fed was to revise and restate the objective of "maximum employment [as] a broad-based and inclusive goal [which] reflects our appreciation for the benefits of a strong labor market, particularly for many in low- and moderate-income communities." ${ }^{x x v i i i}$ In this sense, the Fed acts on inequality in virtue of its mandate. Second, there was a recognition that there are not just synergies between monetary policy and inequality, but also tensions: "Research on the drivers of disparities in labor market outcomes can also help the Federal Reserve better assess potential tradeoffs in monetary policy."xxix Third and finally, however, the emphasis on inclusive growth and on the indirect effects of monetary policy on inequality detracted attention from the direct effects of its actions on rising asset prices (see previous section) and policy alternatives. On this ear, the Fed was not listening.

In sum, the analysis of the Fed and the BoC discourse and research on the links between monetary policy and inequality in the inter-crisis period presents us with a paradox. Both central banks acknowledged that inequality is a concern and recognize the uneven nature of economic cycles. They intensified their research on the distributional dimension of monetary policy with, in 
the Fed's case, a particular emphasis on the notion of inclusive growth and its capacity to help promote this goal. However, and here lies the paradox, this increased engagement did not translate into an intellectual shift on the links between monetary policy and inequality. Rather, central bankers kept on repeating the arguments that were already put forward by Ben Bernanke before the Global Financial crisis: the causes for inequality are mostly found in structural factors, and the best that central bankers can do to address the issue is to achieve their traditional monetary goals (Fontan et al. 2016). This position was reinforced by central bank research on QE programmes, which found them to contribute to inequality reduction, but suffered from obvious methodological limitations.

\section{Ambivalence during the COVID crisis}

The lockdowns implemented to shelter the population from the spread of COVID-19 put intense pressures on the economy as millions of workers faced the threat of job cuts and unemployment. In addition, financial markets gave worrying signs of impending collapse in March 2020 as investors were adjusting to the pessimistic forecasts for the real economy. Against this background, the COVID-19 responses of both the Fed and the $\mathrm{BoC}$ have ventured into uncharted waters with the implementation of new unconventional measures (cf. Table 1). As we shall see in this section, these actions hold interesting lessons about the willingness and capacity of central banks to affect economic inequality. More specifically, they reveal a tension between the capacity of central bank actions to target specific sectors of the economy on the one hand, and their simultaneous affirmation that this is something they are unable to do on the other hand.

When the economic repercussions of the COVID-19 crisis hit in spring 2020, it became clear very quickly that they would be felt very unevenly by different parts of the population. For example, the risk of unemployment was higher among low-income groups, whereas members of privileged groups were both less likely to lose their job and more likely to be able to shift to virtual work. Central banks were keenly aware of these asymmetries. Powell of the Fed underlined in June 2020 that "low-income households have experienced, by far, the sharpest drop in employment, while job losses of African Americans, Hispanics, and women have been greater than that of other groups. If not contained and reversed, the downturn could further widen gaps in economic well-being." $\mathrm{xxx}$

This sensibility to the hardship faced by disadvantaged groups is now also echoed by the BoC. Governor Macklem stated in the spring of 2021 that:

This pandemic has had very unequal effects on Canadians. It has particularly affected lowincome workers, women, racialized Canadians, new immigrants, youth. So we can't just look 
at the aggregates. We've got to look under the hood, we've got to look at things on a more disaggregated level. ${ }^{\mathrm{xxxi}}$

Another indication that the $\mathrm{BoC}$ has recently taken the turn to caring about inequality in terms of marginalized groups and communities is the recent launch of the international Central Bank Network for Indigenous Inclusion, ${ }^{x x x i i}$ of which the $\mathrm{BoC}$ is a founding member.

The observation that the COVID crisis was exacerbating the disadvantageous position of certain groups affected the response of central banks. Recall that during the GFC, the Fed had acted as a "market-maker of last resort" by setting up repurchase facilities (Primary Dealer Credit Facility (PDCF), Money Market Mutual Fund Liquidity Facility, CPFF, TALF) in order to stabilize problematic market segments, such as derivatives and securitized products (Mehrling 2011). On March 17 and 18, 2021, the Fed reactivated three of these facilities to stabilize money markets and to prevent a liquidity crisis. Then, on March 23 and April 9, the Fed opened up its facilities to a range of brand-new economic players, including corporations, community banks providing loans to small firms, as well as municipal and state authorities.

In the same vein, the BoC implemented for the first time in its history a $\mathrm{QE}$ programme by purchasing federal bonds. It also launched the Bankers' Acceptance Purchase Facility (BAPF), which supported lending to SMEs; the Provincial Money Market Purchase Program (PMMP) where the $\mathrm{BoC}$ purchased provincial debt on the primary market, thus directly financing government expenditure; and the Standing Term Liquidity Facility (STLF), which helped commercial banks manage their liquidity risks while "provid[ing] loans to households and businesses when they need it most."

Table 1: The COVID-19 lending facilities of the Fed and the BoC Fed (maximum outstanding amount allotted on May 31st, 2021)

\begin{tabular}{|c|c|c|c|}
\hline Fed Asset Purchase Programmes & Fed (US \$) & BoC (Can \$) & BoC Asset Purchase Programmes \\
\hline $\begin{array}{l}\text { Corporate Credit Facilities (ended } \\
\text { Dec } 31 \text { 2020) }\end{array}$ & $\begin{array}{l}13,757,437,10 \\
7\end{array}$ & $220,000,000$ & $\begin{array}{l}\text { Corporate Bond Purchase Program } \\
\text { (ends May 25, 2021) }\end{array}$ \\
\hline $\begin{array}{l}\text { Term Asset-Backed Securities Loan } \\
\text { Facility (ended Dec } 31 \text { 2020) }\end{array}$ & $1,733,270,661$ & $2,993,000,000$ & $\begin{array}{l}\text { Commercial Paper Purchase Pro- } \\
\text { gram (ended april 2021) }\end{array}$ \\
\hline $\begin{array}{l}\text { Municipal Liquidity Facility (ended } \\
\text { Dec } 312020 \text { ) }\end{array}$ & $5,508,000,000$ & $19,018,000,000$ & $\begin{array}{l}\text { Provincial Bond Purchase Program } \\
\text { (ended May } 6 \text { 2021) }\end{array}$ \\
\hline $\begin{array}{l}\text { Main Street Lending Program } \\
\text { (ended January } 8,2021 \text { ) }\end{array}$ & $\begin{array}{l}16,281,636,33 \\
8\end{array}$ & $7,629,000,000$ & $\begin{array}{l}\text { Provincial Money Market Purchase } \\
\text { Program (ended June } 16 \text { 2021) }\end{array}$ \\
\hline $\begin{array}{l}\text { Paycheck Protection Program Liq- } \\
\text { uidity Facility (still active) }\end{array}$ & $\begin{array}{l}84,226,254,22 \\
2 .\end{array}$ & $38,766,000,000$ & $\begin{array}{l}\text { Bankers' Acceptance Purchase Fa- } \\
\text { cility (ended nov 2021) }\end{array}$ \\
\hline
\end{tabular}


What is noteworthy about these respective policy responses is that they explicitly and intentionally target specific sectors of the economy. This approach stands in marked contrast with central bank interventions prior to the COVID-19 crisis, and operates through two different channels. First, a direct channel through which the central bank funnels liquidity directly to a variety of economic actors: For example, the Fed implemented the Paycheck Protection Program, which aimed at providing "critical support to small businesses" and to specific communities that are often beyond the reach of conventional monetary policy. Speaking in front of representatives of community banks, Brainard acknowledged that "Your firsthand experiences of working with minority borrowers and your knowledge of local communities make you essential partners in better targeting our tools to assist low-income and minority small businesses and communities". xxiv In other words, the Fed carefully set up its liquidity facilities to make sure that its credit lines would be accessible to a very wide range of economic actors, especially those lending to the minorities that were the most affected by the crisis. Similarly, the Fed's Main Street lending program targeted "medium-sized companies and smaller companies that sort of fall between the PPP program and the corporate credit facilities [...] [and] we had to create standardized products that would meet the needs of as broad as possible a range of companies." In fact, this program was able to reach very specific economic players, including "small and medium-sized nonprofit organizations, such as hospitals and universities." ${ }^{x x x}$ Interestingly, Powell went out of his way to underscore the unusual character of these programs. Powell underlined that the Fed was in a good position because it has "very specific powers, which are lending powers (...) that we have used to a completely unprecedented extent here." Indeed, by creating specific facilities for specific kind of borrowers, the Fed "worked hard" to respect the "maximum employment" objective of its double mandate because "it's not so simple (to reach) Main Street" with regular monetary tools.

The $\mathrm{BoC}$ created similarly targeted programs to ensure continued direct access to liquidity for businesses and households with its Bankers' Acceptance Purchase Facility, the Standing Term Liquidity Facility, and the Canada Mortgage Bond Purchase Program. Once again, these tools provided localized access to liquidity that conventional monetary policy instruments are unable to provide. Because they are tailored to the needs of those most adversely affected by the COVID19 crisis, the Fed's and the BoC's policies have arguably helped to contain inequality.

The second channel through which central banks have injected liquidity in response to the COVID-19 crisis is by boosting public finances at different levels of government. Not only did they use quantitative easing - for the first time in the BoC's case - to buy government bonds on secondary markets, but some of their new programs broke the taboo against direct government financing through the purchase of bonds on primary markets (Turner 2017, chapter 14). ${ }^{\text {xxvi }}$ Both the Fed's Municipal Liquidity Facility and the BoC's Provincial Money Market Purchase 
Program directly bought both state / provincial and municipal bonds. To the extent that the different levels of governments used these funds for measures designed to mitigate the k-shaped recovery, the central banks contributed to containing inequality through this channel, too.

In sum, in response to the COVID-19 crisis, both the Fed and the BoC have taken measures to cushion the inegalitarian fallout from the crisis. Two caveats should be added here. First, many of these measures were temporary and discontinued within twelve months of the onset of the crisis. Second, the lending rate attached to these facilities was "based on a rate that is a premium to normal market," the Fed's justification for this premium being that the central bank should act as "a backstop lender (and) not as a first stop that replaces private capital." These specific settings explain why most of these facilities were actually not used much by the economic players ${ }^{\text {xxxvii }}$, with the exception of the PPP. These two caveats notwithstanding, the measures clearly demonstrate that unconventional monetary policy can target specific economic sectors or subgroups of the population.

In stark contrast with these actions as well as with some of the justifications provided for them, representatives from both central banks have recently gone out of their way to reaffirm old discursive tropes about the alleged bluntness of monetary policy and its incapacity to target specific economic sectors. For instance, when asked by a member of Congress about what the Fed could do to help African-American communities in the midst of the pandemic, Powell acknowledged first that, despite the new Fed facilities, "there are persistent [employment] gaps and they are very troubling". However, he then went on to say:

[These gaps] are not, in the long run, something that monetary policy can address. It really is up to other policies, by governments, State and local governments, the Federal Government, and frankly businesses, to do what they can to close that gap. What we have is an interest rate tool, and what we can do is support the goals you have given us: maximum employment; and stable prices. We see positive effects from that. But over the longer run, broader policies of education and other things would help with that issue."xxxviii

The BoC policymakers expressed a similar degree of unease when providing a rationale for their new facilities. On the one hand, when speaking to the considerations that enter the choice of a monetary policy framework, Carolyn Wilkins recognized that "[w]hen it comes to other objectives - climate change, income inequality - income inequality is certainly something we can take into account when we pick a framework."xxxix On the other hand, despite this increased awareness and openness to consider distributive issues, Wilkins immediately underlined that "monetary policy is a blunt instrument and can't pick and choose where growth happens." Put differently, "we know that monetary policy is a broad macroeconomic instrument that cannot target specific sectors or workers." ${ }^{\times 1}$ In short, what central banks including the BoC seem to be 
saying is: Look, even if you wanted us to act on inequality (read: even if you changed our mandate), there is no point because our policy instruments are just not cut out for this task.

Given their COVID-19 response and its demonstration to the contrary, these statements by the Fed and the BoC are puzzling to say the least. To claim that they cannot act on inequality is

bizarre, because they just did act on inequality. Nor is the insight about this possibility new. The French economist Cantillon (1755) observed already in the $18^{\text {th }}$ century that liquidity injections into the economy benefit some more than other, depending on where in the economy the liquidity is injected and how the stimulus is designed.

Given the incentives structure of central bankers to preserve their independence, they perhaps want to claim that central banks should not act on inequality but that, ${ }^{\text {xli }}$ as we have seen in section 4 , is a different question.

\section{Conclusion}

We have argued in this paper that while the Fed and the BoC have come a long way in their discourse on inequality, and even to some extent in their actions to contain inequality, their positions on the issue still suffer from a number of inconsistencies and shortcomings.

During the inter-crisis period from 2015 to 2020, the Fed and the BoC devote more and more attention to the issue of inequality. With its emphasis on inclusive growth, the Fed in particular implicitly recognizes that inequality matters not just for instrumental reasons, but for its own sake. While this should certainly be welcomed as progress, the case of the BoC vividly illustrates that central bankers still get themselves into a conceptual muddle when probed about the inegalitarian impact of their own policies. One particularly important shortcoming of their discourse on this issue is their failure to compare their actions to alternative policies rather than simply to no intervention at all. Finally, our analysis shows both the Fed's and the BoC's conviction prior to COVID-19 that monetary policy has no role to play in fighting inequality, in large part because its instruments are too blunt for the task.

Their crisis response to COVID-19 reveals a deep tension in their position, because it demonstrates that, contrary to what central bankers have claimed and continue to claim, unconventional monetary policy can target specific economic sectors and, thus, can contribute to contain inequality.

Someone might object that the COVID-19 response is not really about monetary policy alone, but monetary policy cum fiscal policy, and that the distributive impact comes from the fiscal component. That may be correct with respect to some of the programs - e.g. with respect to buying provincial debt on the primary market - but note that this aspect is contingent. Just think 
of so-called helicopter money as one potential illustration. The distributive impact of a liquidity injection by helicopter drop is highly likely to be less inegalitarian compared to a liquidity injection by QE.

Finally, even if new monetary facilities can temporally alleviate the economic hardship faced by the least well off, do they have the potential to create similar effects on the middle and long term? After all, Powell mobilized this argument to pass the hot potato to the government (cf. supra). However, if the long run neutrality of money is intellectually dead as we mentioned earlier, why would not it be the same for these new facilities? First, even if these new facilities are temporary, they have surely triggered long-term positive effects by preventing short-term job losses and business foreclosures and, in turn, middle and long term economic hardship. ${ }^{\text {xli }}$ Second, if economic inequality has a structural component and these new facilities help to reduce employment gaps as central bankers themselves acknowledge, why not make them permanent? Central bankers tend to assign the responsibility for economic inequality to various governmental policies (education, fiscal policy, labour market policy, etc.). Yet, even if they were right on this issue, which is far from obvious, why would we, as a society, refrain from using other tools, such as monetary policy, to decrease economic inequality? Central bankers might answer that this is not in their mandate or that it induces undesirable trade-offs (such as lower independence level or suboptimal performance on price stability), but this answer opens the debate rather than closes it (Dietsch et al., 2018). Our goal here is not to advocate a specific set of alternative policies. It is merely to point out that the BoC's and the Fed's responses to the COVID-19 crisis illustrate what can be done and, thus, belies their discourse that monetary policy is too blunt a tool to address inequality. Perhaps conventional monetary policy was indeed too blunt to do that, but policy innovation in response to the COVID-19 crisis has shown that unconventional monetary policy can certainly be one tool among others when it comes to reducing inequality. The cat is out of the bag, and we need to think constructively about how to manage it.

\footnotetext{
${ }^{\mathrm{i}}$ The chapter can be interpreted as a continuation of our work on the Fed, the European Central Bank, and the Bank of England and their response to the financial crisis of 2007 (see Fontan et al. 2016).

ii The appendix is at: https://doi.org/10.5281/zenodo.5579878

iii For example, we shall see that the Bank of Canada explicitly appeals to the idea as recently as 2018.

iv This three-way distinction also informed the structure of some of our previous work on the relation between central banks and inequality. See Fontan et al. (2016).

${ }^{\mathrm{v}}$ For the general review process, see https://www.bankofcanada.ca/core-functions/monetary-policy/agreementinflation-control-target/ (last accessed 2021-05-31). For information on the latest round of review, see https://www.bankofcanada.ca/toward-2021-renewing-the-monetary-policy-framework/toward-2021-outreach/ (last accessed 2021-05-31).

${ }^{v i}$ Bernanke, 6 February 2007

vii Wilkins, 18 April 2017.
} 
viii Powell, 17 July 2018.

${ }^{\text {ix }}$ A parallel, albeit much earlier, shift can be observed in the philosophical literature on inequality over the last half century, where the assumptions of liberalism have been criticized for implicit bias in terms of race (e.g. Mills, 1997), gender (e.g. Okin 1989), or ethnic minority (e.g. Kymlicka 1995).

${ }^{\mathrm{x}}$ Yellen, 22 June 2016. For a concrete example of the kind of research done at the Fed and its regional offices in this regard, see e.g. Gerardi et al. (2020).

${ }^{x i}$ The campaign was led by the Center for Popular Democracy, see http://whatrecovery.org/ (last accessed 2021-0528)

xii Transcript from the Wall Street Journal Pro, 26 August 2016.

xiii Wall Street Journal Pro, 26 August 2016.

xiv Ibid.

${ }^{\mathrm{xv}}$ Yellen, 28 March 2017.

${ }^{\text {xvi }}$ Clarida, 5 June 2019.

xvii Wilkins, 20 November 2018.

xviii Wilkins, 18 April 2017.

${ }^{x i x}$ Wilkins explicitly grants this point elsewhere: "Different monetary policy frameworks can have different implications for [...] the distribution of income and wealth." (Wilkins, 20 November 2018)

${ }^{x x}$ Powell, 18 July 2018.

${ }^{x x i}$ Most of the critical assessment of recent research on the distributive effects of quantitative easing in the rest of this section is a translation from our article in French (Claveau et al. 2020).

xxii Macklem, 12 March 2012.

xxiii Yellen, 17 November 2016.

xxiv Powell, 17 July 2018.

${ }^{x x v}$ Yellen, 3 March 2017.

xxvi Yellen, 22 June 2016.

xxvii Another consideration that might play a role in the background here is that the $\mathrm{BoC}$ has sometimes emphasized that any change to its policy framework risks undermining the credibility of its inflation target and, as such, needs to be backed by strong reasons in its favour. Consider former Deputy Director Agathe Côté, who stated in 2014 that "any modification to the framework must be thoughtfully researched and carefully considered. This doesn't mean there is no room for improvement, just that [...] the bar for change is high." (Côté, 18 November 2014.

xxviii Powell, 27 August 2020.

${ }^{\text {xxix }}$ Brainard, 27 September 2017.

${ }^{\mathrm{xxx}}$ Powell, 16 June 2020. See also Brainard, 1 December 2020.

${ }^{x x x i}$ Citation from the Globe and Mail (Rendell 2021). See also Macklem and Wilkins, 26 November 2020 for an unequivocal concern voiced by $\mathrm{BoC}$ officials "that this pandemic is widening divides in society."

${ }^{\text {xxxii }}$ See https://www.bankofcanada.ca/2021/04/bank-canada-becomes-inaugural-member-of-new-internationalcentral-bank-network-indigenous-inclusion/ (last accessed 2021-07-15).

xxxiii See https://www.bankofcanada.ca/markets/market-operations-liquidity-provision/covid-19-actions-supporteconomy-financial-system/ (last accessed 2021-07-05 ).

xxxiv Brainard, 15 October 2020.

${ }^{x x x v}$ See https://www.federalreserve.gov/newsevents/pressreleases/monetary20200717a.htm (last accessed 2021-07$08)$.

${ }^{x x x v i}$ Contrast this with the response to the GFC. When a member of The Fed Board was asked back in 2009 why the Fed did not intervene in the municipal bond markets then, he answered "the Federal Reserve has important 
misgivings about assuming such a role in light of the potential for decisions about the provision of credit to states and municipalities to assume a political dimension."

xxxvii The lack of use of these facilities do not mean that they were useless: their mere announcement was instrumental in stabilizing the targeted markets.

xxxviii Powell, 11 February 2020.

xxxix Macklem and Wilkins, 26 November 2020.

${ }^{\mathrm{xl}}$ Macklem, 10 September 2020.

${ }^{x l i}$ For the opposite position, see for instance Hockett and James (2020).

xlii This argument is similar to the hysteresis effect put forward by Blanchard and Summers (1992). 


\section{References}

Amano, R., Carter, T., \& Terajima, Y. (2017). Redistributive Effects of a Change in the Inflation Target (Staff Analytical Note No. 2017-13). Ottawa, Ontario: Bank of Canada.

Ampudia, M., Georgarakos, D., Slacalek, J., Tristani, O., Vermeulen, P., \& Violante, G. (2018). Monetary Policy and Household Inequality (Discussion Papers No. 2170). ECB Working Paper Series. Frankfurt: European Central Bank. Retrieved April 8, 2019, from $<\underline{\text { https://papers.ssrn.com/abstract }=3223542>}$

Bank of Canada. (2016). Renewal of the Inflation-Control Target: Background Information., p. 39. Ottawa: Bank of Canada.

Bank of England. (2012). The Distributional Effects of Asset Purchases ( No. 73), p. 22. London: Bank of England.

Best, J. (2018). 'Technocratic Exceptionalism: Monetary Policy and the Fear of Democracy', International Political Sociology, 12/4: 328-45. DOI: 10.1093/ips/oly017

Bivens, J. (2015). 'Gauging the impact of the Fed on inequality during the Great Recession', Hutchins Center Working Papers.

Blanchard, O. J., \& Summers, L. H. (1992). 'Hysteresis in unemployment'. Garonna P., Mori P., \& Tedeschi P. (eds) Economic Models of Trade Unions, International Studies in Economic Modelling, pp. 235-42. Springer Netherlands: Dordrecht. DOI: 10.1007/978-94-011-2378$\underline{5 \quad 11}$

Cantillon, R. (1997). Essai sur la nature du commerce en general. Paris: Institut National d'Etudes Démographiques.

Coibion, O., Gorodnichenko, Y., Kueng, L., \& Silvia, J. (2012). Innocent Bystanders? Monetary Policy and Inequality in the U.s. NBER Working Paper 18170, Cambridge, MA.

Colciago, A., Samarina, A., \& Haan, J. de. (2019). 'Central Bank Policies and Income and Wealth Inequality: A Survey', Journal of Economic Surveys, 1-33. DOI:

10.1111/joes. 12314

Dietsch, P., Claveau, F., \& Fontan, C. (2018). Do Central Banks Serve The People?. Future of Capitalism series. Cambridge: Polity.

El-Erian, M. A. (2017). The only game in town: central banks, instability, and avoiding the next collapse. New York: Random House. 
Fabo, B., Jančoková, M., Kempf, E., \& Pástor, L. (2021). 'Fifty shades of QE: Comparing findings of central bankers and academics', Journal of Monetary Economics. DOI: 10.1016/j.jmoneco.2021.04.001

Fontan, C., Claveau, F., \& Dietsch, P. (2016). 'Central banking and inequalities: Taking off the blinders', Politics, Philosophy \& Economics, 15/4: 319-57.

Gerardi, K., Willen, P., \& Zhang, D. H. (n.d.). 'Mortgage Prepayment, Race, and Monetary Policy', Federal Reserve Bank of Atlanta, Working Papers, 2020/22.

Hockett, R., \& James, A. (2020). Money from nothing: or, why we should learn to stop worrying about debt and love the Federal Reserve. Brooklyn, NY: Melville House.

Ingham, G. K. (2004). The nature of money. Cambridge, UK; Malden, MA: Polity.

Ingham, G. K.. (2020). Money. What is political economy? Cambridge, UK; Medford, MA: Polity.

Kymlicka, W. (1995). Multicultural citizenship: a liberal theory of minority rights. Oxford; New York: Clarendon Press; Oxford University Press.

Lenza, M., \& Slacalek, J. (2018). How Does Monetary Policy Affect Income and Wealth Inequality? Evidence from Quantitative Easing in the Euro Area (Working Paper No. 2190). ECB Working Paper Series. Frankfurt am Main: European Central Bank. Retrieved April 8, 2019, from $<\underline{\text { https://papers.ssrn.com/abstract }=3275976}>$

Mehrling, P. (2011). The new Lombard Street: how the fed became the dealer of last resort. Princeton, N.J.: Princeton Univ. Press.

Mills, C. W. (1997). The Racial Contract. Cornell University Press.

Minsky, H. (1993). 'On the non-neutrality of money', Quarterly Review, 18/Spr: 77-82. Federal Reserve Bank of New York.

Okin, S. M. (1989). Justice, gender, and the family. New York: Basic Books.

Rawls, J. (1999). A Theory of Justice, Revised Edition. Cambridge, Mass: Belknap Press of Harvard University Press.

Rendell, M. (2021). 'Canadian economy won't fully recover until inequality addressed, BoC's Macklem says'. The Globe and Mail.

Rochon, L.-P., \& Olawoye, S. 'Yinka (Eds). (2012). Monetary policy and central banking: new directions in post-Keynesian theory. Cheltenham: Edward Elgar. 
Tobin, J. (1972). 'Friedman's Theoretical Framework', Journal of Political Economy, 80/5: 85263. The University of Chicago Press. DOI: $10.1086 / 259941$

Tucker, P. (2018). Unelected power: The quest for legitimacy in central banking and the regulatory state. New Jersey: Princeton University Press.

Turner, A. (2017). Between debt and the devil: money, credit, and fixing global finance. Princeton: Princeton University Press.

WSJ Pro. (2016). 'Transcript: Fed Officials Meet With Fed Up Activists at Jackson Hole'. Wall Street Journal. 


\section{Appendix I: Cited documents from our corpus}

Bernanke, Ben (Federal Reserve), 6 February 2007, 'The level and distribution of economic well-being', before the Greater Omaha Chamber of Commerce, Omaha, Nebraska. https://www.federalreserve.gov/newsevents/speech/bernanke20070206a.htm

Brainard, Lael (Federal Reserve), 27 September 2017, 'Labor Market Disparities and Economic Performance', at 'Banking and the Economy: A Forum for Minority Bankers,' Federal Reserve Bank of Kansas City, Kansas City, Missouri. https://www.federalreserve.gov/newsevents/speech/brainard20170927a.htm

Brainard, Lael (Federal Reserve), 15 October 2020, 'Modernizing and Strengthening CRA Regulations: A Conversation with Minority Depository Institutions', to the National Bankers Association. https://www.federalreserve.gov/newsevents/speech/brainard20201015a.htm

Clarida, Richard H. (Federal Reserve), 5 June 2019, 'The Federal Reserve's review of its monetary policy strategy, tools, and communication practices', at the Conference on Monetary Policy Strategy, Tools, and Communication Practices (Fed Listens Event), hosted by the Federal Reserve Bank of Chicago, Chicago, Illinois. https://www.bis.org/review/r190607f.htm

Côté, Agathe (Bank of Canada), 18 November 2014, 'Inflation Targeting in the Post-Crisis Era', at the Calgary CFA Society, Calgary, Alberta. https://www.bankofcanada.ca/2014/11/inflation-targetingpost-crisis-era/

Macklem, Tiff (Bank of Canada), 12 March 2012, 'Promoting Growth, Mitigating Cycles and Inequality: The Role of Price and Financial Stability', at the 'Brazil-Canada Chamber of Commerce,' São Paulo, Brazil. https://www.bankofcanada.ca/2012/03/promoting-growth-mitigating-cycles-andinequality/

Macklem, Tiff (Bank of Canada), 10 September 2020, at the Canadian Chamber of Commerce (virtually). https://www.bankofcanada.ca/2020/09/economic-progress-report-a-very-uneven-recovery/

Macklem, Tiff (Bank of Canada) and Carolyn A. Wilkins (Bank of Canada), 26 November 2020, at Testimony before the Standing Committee on Finance, House of Commons, Government of Canada. https://www.ourcommons.ca/DocumentViewer/en/43-2/FINA/meeting-7/evidence

Powell, Jerome (Federal Reserve), 17 July 2018, 'Federal Reserve's Second Monetary Policy Report for 2018', at Hearing before the Committee on Banking, Housing, and Urban Affairs, U.S. Senate. https://www.govinfo.gov/content/pkg/CHRG-115shrg32517/html/CHRG-115shrg32517.htm

Powell, Jerome (Federal Reserve), 18 July 2018, 'Monetary Policy and the State of the Economy', at Hearing before the Committee on Financial Services, U.S. House of Representatives. https://www.govinfo.gov/content/pkg/CHRG-115hhrg31509/html/CHRG-115hhrg31509.htm

Powell, Jerome (Federal Reserve), 11 February 2020, 'Monetary Policy and the State of the Economy', at Hearing before the Committee on Financial Services, U.S. House of Representatives. https://www.govinfo.gov/content/pkg/CHRG-116hhrg42819/html/CHRG-116hhrg42819.htm 
Powell, Jerome (Federal Reserve), 17 June 2020, 'Semiannual Monetary Policy Report to the Congress', at Hearing before the Committee on Banking, Housing, and Urban Affairs, U.S. Senate. https://www.federalreserve.gov/newsevents/testimony/powell20200616a.htm

Powell, Jerome (Federal Reserve), 27 August 2020, 'New Economic Challenges and the Fed's Monetary Policy Review', at the 'Navigating the Decade Ahead: Implications for Monetary Policy', Federal Reserve Bank of Kansas City economic policy symposium, Jackson Hole, Wyoming. https://www.federalreserve.gov/newsevents/speech/powell20200827a.htm

Wall Street Journal Pro, 26 August 2016, 'Transcript: Fed Officials Meet With Fed Up Activists at Jackson Hole', meeting held on the $25^{\text {th }}$ of August 2015, at Jackson Hole, Wyoming. https://www.wsj.com/articles/transcript-fed-officials-meet-with-fed-up-activists-at-jackson-hole$\underline{1472234174}$

Wilcox, David (Federal Reserve), 20 May 2009, 'Municipal finance', before the Committee on Financial Services, U.S House of Representative, Washington, D.C. https://www.federalreserve.gov/newsevents/testimony/wilcox20090521a.htm

Wilkins, Carolyn A. (Bank of Canada), 18 April 2017, 'Blame It on the Machines?', before the Toronto Region Board of Trade, Toronto. https://www.bankofcanada.ca/2017/04/blame-it-on-the-machines/

Wilkins, Carolyn A. (Bank of Canada), 20 November 2018, 'Choosing the Best Monetary Policy Framework for Canada', at the McGill University Max Bell School of Public Policy, Montreal. https://www.bankofcanada.ca/2018/11/choosing-best-monetary-policy-framework-canada/

Yellen, Janet (Federal Reserve), 22 June 2016, 'Monetary Policy and the State of the Economy', at Hearing before the Committee on Financial Services, U.S. House of Representatives. https://www.govinfo.gov/content/pkg/CHRG-114hhrg25848/html/CHRG-114hhrg25848.htm

Yellen, Janet (Federal Reserve), 17 November 2016, 'The Economic Outlook', at Hearing before the Joint Economic Committee, Congress of the United States. https://www.govinfo.gov/content/pkg/CHRG-114shrg23027/html/CHRG-114shrg23027.htm

Yellen, Janet (Federal Reserve), 3 March 2017, 'From Adding Accommodation to Scaling It Back', at the Executives' Club of Chicago, Chicago, Illinois. https://www.federalreserve.gov/newsevents/speech/yellen20170303a.htm

Yellen, Janet (Federal Reserve), 28 March 2017, 'Addressing Workforce Development Challenges in Low-Income Communities', at 'Creating a Just Economy', the 2017 annual conference of the National Community Reinvestment Coalition, Washington, D.C. https://www.federalreserve.gov/newsevents/speech/yellen20170328a.htm 